\title{
UPDATE ON TAX CONTROL PRACTICE IN LATVIA IN THE SCOPE OF VAT DIRECTIVE 2006/112/EC
}

\author{
Inta Brūna \\ University of Latvia \\ Jūlija Pouha \\ University of Latvia
}

\begin{abstract}
Topicality of the problem under discussion is related to a complicated situation arising between a taxpayer and State Revenue Service (SRS) of Latvia in connection with application of law, when settling disputes arising in the process of tax administration. There are topical problems of tax audit in application of particular laws on value added tax (VAT) analysed in the research. The goal of this research is to analyse how evidence during a tax audit is gathered in the Latvian tax administration and on what basis considerations are made, which become conclusions for a tax audit carried out later on, and to draft recommendations for improvement of the current situation on the basis of findings. The article summarizes information regarding assessment of impartiality of the audit evidence obtained by the SRS in accordance with the criteria of eligibility and sufficiency. From the point of view of emerged practice of auditors, interpretation of specific provisions of tax laws is also carried out that affects exercise of the legitimate rights of taxpayers in disputes with the SRS significantly, as well as established practice of the Supreme Court (SC) of Latvia and latest considerations in the EU judicature. The study resulted in identification of the key problems in tax auditing and the conclusion made that the methodical practice of the SRS must be reviewed due to incompliance with the EU case law, which leads to incompliance with the general principles of law in mutual relations between the state and taxpayers.
\end{abstract}

Keywords: tax audit, tax audit evidence, criteria for deducting pre-tax, judicature

JEL code: $\mathrm{H} 210$

\section{Introduction}

The resources required for implementation of the state functions are provided by a definite amount of the state budget, but tax revenue constitutes a significant part thereof. Law "On the State Revenue Service of the Republic of Latvia" stipulates that the main task of the Service is "... to ensure collection of state taxes, duties, and other state-defined mandatory payments administered by the State Revenue Service on the territory of Latvia and on the customs border, as well as collection of taxes, duties, and other mandatory payments for the budget of the European Union" (VID, 1993). The report drafted by the State Audit Office (SAO) in 2015 on the audits carried out for the 2014 reports, having analysed the action of the SRS action and justifying the conclusions with the statistical indicators, characterizes the existing situation in the area of state revenue comprehensively and gives their views on the operation of the SRS in the area of tax administration that provides the vast part of the revenue in the state budget. Statements provided by the SAO include explanations on actual implementation of the budget, measures of tax control carried out, tax arrears, efficiency of tax recovery, and opinion on the overall performance of the SRS. Studying the 2014 report, the SAO gave the following opinion: "Actions of the SRS are focused on arrangement of fair competition environment only partially ... there is inconsistent and unequal treatment of taxpayers observed" (LR VK, 2014), which was taken as the basis for an in-depth study in the scope of this research. 
Therefore, the overall goal of this research is to analyse how evidence during a tax audit is gathered in the Latvian tax administration and on what basis considerations are made, which become conclusions for a tax audit carried out later on, and to draft recommendations for improvement of the current situation on the basis of findings. The following objectives are set forth for the achievement of the goal defined:

1) Describe the current situation in the area of tax collection in Latvia;

2) Identify the most problematic tax and study problems related with the collection of VAT;

3) Analyse the criteria of eligibility put forward by the generally accepted international practice in auditing from the point of view of International Standards on Auditing for the evidence obtained to be recognized as sufficient and valid for provision of conclusions;

4) Develop recommendations on how the tax audit can be improved in Latvia for solution of the problems identified based on international expertise.

There is an analytical method for studying the laws, court judgments, audit reports, and scientific literature; a comparative method for assessing certain court judgments pursuant to general practices of auditors, judicature of the Republic of Latvia and the EU; and an inductive method for describing the resulting conclusions of the author and formulating proposals applied in the paper.

The research findings are summarized in the information, which is structured according to the goal and objectives of the research, starting from the justification of the actual situation and identification of VAT as one of the most problematic taxes, and clarification of the reasons of the negative collection trends to legal justification and criteria of deduction of VAT pre-tax according to the best practices collected in the judicature of the Supreme Court of Latvia. In conclusion, the authors draw conclusions and formulate recommendations for improvement of tax auditing process in Latvia.

\section{Description of the Current Situation in Tax Collection in Latvia}

In Latvia, there are currently unresolved issues arising from each other: tax evasion and excessive tax burden, as noted by the European Committee (EC) in its working document "Country Report Latvia 2015", which deals with performance of every country in comparison with other Member States of the European Union (EU) in 2015. Regarding prospects of tax administration for the next few years in Latvia, the EC voiced its opinion as follows: "Sufficiency of resources and practice of the tax administration professionals is not adequate in order to increase their capacity to solve complicated problems of financial crimes. The sanctions that are determined in the courts for tax evasion and tax avoidance are not sufficiently focused on results" (Country Report Latvia, 2015).

The document "Latvia's Stability Programme for 2015-2018 (Riga, 2015)" mentions several guidelines for development in a medium-term and long-term period, including planned visions in the state budget as well. The planned changes within the fiscal policy affect collection of VAT as one of the most problematic taxes in 2015-2018 in such a manner:

Value Added Tax. In spite of the reduction of VAT revenue growth rate, stable VAT revenue growth is expected according to the forecasted country's economic growth. In addition, in the medium term, the VAT revenue growth will be facilitated by the continued implementation of the measures adopted by the government - the fight against tax evasion and tax avoidance improving efficiency of tax collection. Improvements in tax collection will result in gradual increase in the amount of tax revenue to GDP. The VAT revenue is affected also by the 
measures that are not directly related to the changes in the VAT Law, but contributing to revenue growth. (Latvia's Stability Programme for 2015-2018) At the same time, the following statement is found regarding the medium-term development trends: “... increasing the tax revenue ratio to $1 / 3$ of GDP, primarily through better tax collection". (Latvia's Stability Programme for 2015-2018)

The aforementioned indicates clearly to the fact that "improving efficiency of tax collection" must provide opportunities for the tax administration to collect taxes and duties more efficiently if compared with previous years. This is also reflected in objectives of the Latvian fiscal policy as clear increase in the collected taxes. However, the real situation consisting of actual figures demonstrates significant deviations from the intentions described in the documents, due to what the State Revenue Service of the Republic of Latvia published a report with the following content:

Payments of value added tax from the mentioned taxpayers in eight months of 2016 if compared with the corresponding period in 2015, decreased by 20.55 million euro or $27.1 \%$. (Astoņos mēnešos ... 2016). Such significant deviations justify the need for a more detailed analysis of VAT collection and tax auditing.

In Latvia, the Saeima (Parliament) of the Republic of Latvia is responsible for ensuring the formation of the state budget and its use in the public interest, that is, function of the budget formation, whereas the functions of the Ministry of Finance include development, coordination, and implementation of financial policy. The State Revenue Service (SRS), an authority subordinate to the Ministry of Finance, provides the implementation of financial policy on the revenue side by administrating taxes and taking part in enforcement of anticorruption policy. Thus, while implementing the supervisory function of tax payment, the SRS is forced to carry out control procedures enabling to detect tax offenses. The Latvian Law "On Taxes and Duties" provides for three types of inspection: 1) data compliance inspection; 2) thematic inspection; and 3) tax audit. Violations in the calculation of taxes are detected in the result of tax audits, and significant penalties are applied to taxpayers for that offence. (On Taxes and Duties, 1995)

The SRS-administered tax arrears are structured pursuant to classification of tax arrears as per possibility of their collection. Critical situation in the revenue of the Latvian state budget is observed for several years already, because the largest proportion of tax arrears is actually uncollectable tax arrears and they tend to increase every year, whereas an amount of actually collectable tax arrears decreases every year. Despite the fact that the problem persists for a long period of time, there is no understanding gained on the causes of this trend and official position does not exist up to date. Therefore, fight against this phenomenon is not possible in the perspective until the causes are not identified.

Having studied the published conclusion of the State Audit Office of the Republic of Latvia on the 2014 report on the implementation of the state budget and local government budgets, there is information on the deliverables of tax administration process, the progress of implementing the improvements proposed by the State Audit Office in previous years, and statistical analysis of the tax revenue share, structure of tax arrears. The data about a proportion of really calculated, but uncollectible taxes in absolute terms out of all tax arrears in million euro is very significant. (Figure 1).

Proportion of uncollectable taxes continues to grow every year and it reached $85 \%$ of the total tax arrears or 836 million euro as of the end of 2014 from 1,402.5 million euro. 
The total debt of the payments to the state budget administered by the State Revenue Service (SRS) was 1.425 billion euro as of 1 August 2016, according to the information available on the website of the SRS. Out of the total debt, 888.89 million euro or $62.36 \%$ are realistically uncollectible debts. Out of the total debt, the tax arrears that must be collected in accordance with the laws and regulations constitute 1.032 billion euro or $72.37 \%$, whereas realistically collectable debts constitute only 142.775 million euro or $10.02 \%$ of the total debt. (LR VK, 2014)

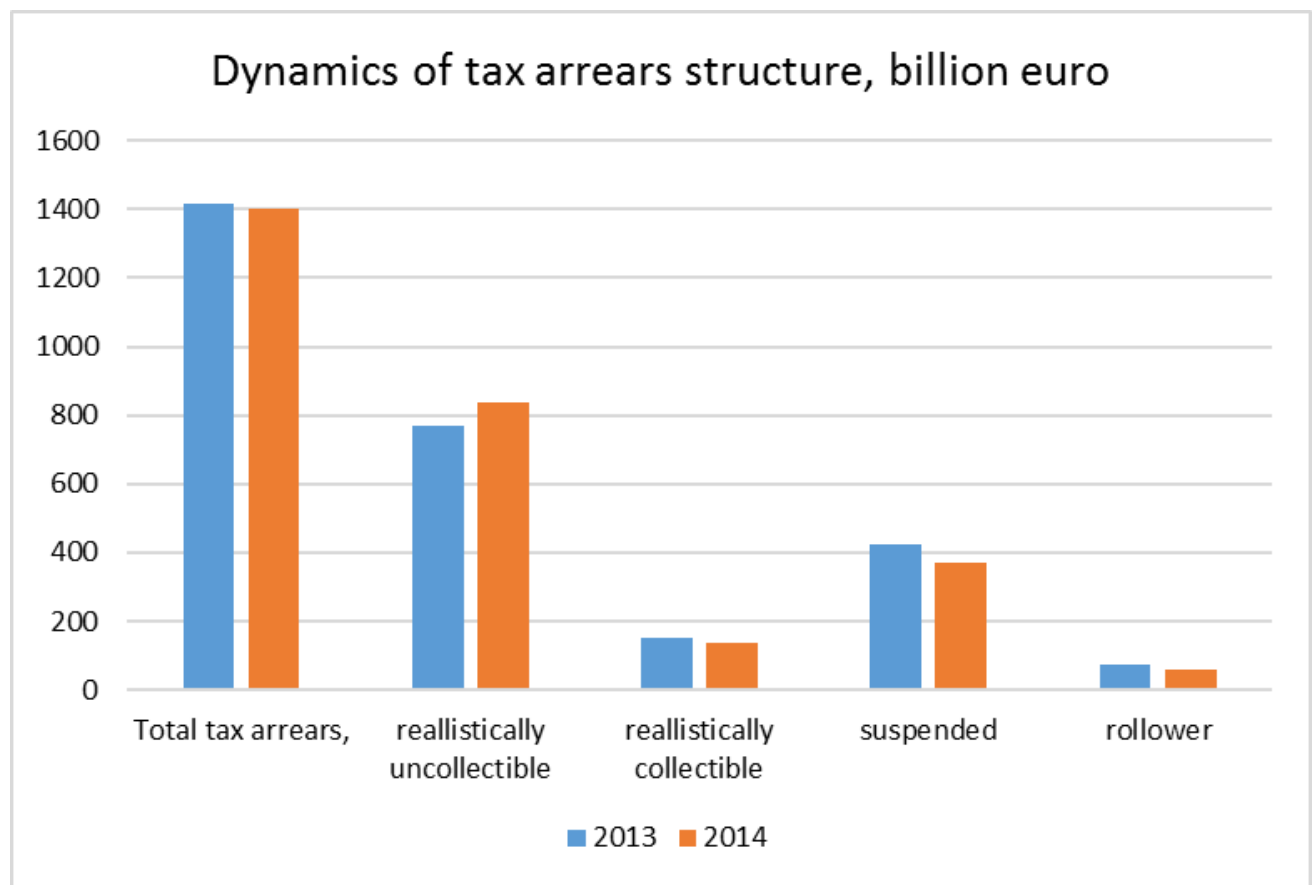

Figure 1. Dynamics of tax arrears structure in Latvia 2013-2014 (prepared by authors based on LR VK, 2014)

\section{Causes of Negative Tax Collection Trends}

A significant percentage of uncollectible taxes and its increase in the overall tax structure allows proposing two hypotheses about possible causes, which is the basis for recovery being impossible:

1) Inefficient tax recovery mechanism;

2) Additional sums of taxes calculated disproportionately in the result of tax control.

In this context, the SAO also provided data on a ratio of additionally calculated payments at an average audit as per average tax payments of a taxpayer and concluded that the taxes calculated during tax audits exceeded average tax payments of legal entities per year (4.8 times) (LR VK, 2014), which leads to impossibility to pay taxes due to excessive premium due.

During audits of financial annual accounts for 2011, 2013 and 2014, the State Audit Office issued a recommendation to the Ministry of Finance to identify the reasons behind the low level of tax arrears collection and to find a solution to improve the existing situation. The Ministry of Finance undertook to study the situation and prepare an official memorandum on the causes of the low level of tax arrears collection by 15 October 2016. While such official report is being drafted on the deficiencies identified in tax recovery, the authors highlight two fundamental problems having summarized the previously mentioned: 1) increasing proportion of actually uncollectible tax arrears in the structure of total debt and in the state budget 
accordingly, 2) increasing amount of additionally calculated taxes in the result of tax control measures.

According to the authors, both problems are intertwined and create a causal link, because the control measures result in the amounts calculated, which are actually uncollectable. Thus, in order to understand the impossibility of tax arrears recovery and to develop affirmative measures, source of their origin and validity of calculated taxes must be carefully studied. In other words, one must explore how the tax administration comes to the need to calculate additional taxes in the result of audit, which taxes are most often audited, and what are the reasons for that.

It is often argued that there are both signs of inconsistent action during tax audits and contradictions in the interpretation of specific provisions of tax laws apparent in the operation of the SRS. The Tax Control Board of the SRS carried out 1,243 tax audits in 2015 (1,003 tax audits of legal entities, 240 tax audits of individuals), out of which 1,181 tax audit were fruitful (effectiveness is 95\%), while Latvian Court Portal (LCP) shows that according to the data provided by the Administrative District Court and the Administrative Regional Court, a number of pending cases constituted 511 at the end of 2015, where the SRS was one of the parties (LCP, 2016). In turn, the SRS 582 carried out 582 tax audits in the first half of 2016, of which 552 tax audits were fruitful. During the tax audits in the first half of 2016, additional taxes were calculated in the amount of 149.7 million euro. The largest share of taxes, where additional calculations were made in the first half of 2016, was value added tax - 54\% (80.7 million euro) of the total sum calculated during the tax audits (Nodoklı kontroles..., 2016).

\section{Legal Basis of VAT Audit and Criteria for Recognition of Pre-tax}

The above data confirms the need to evaluate both the VAT regulatory framework and legal support to the tax authority and judicial authorities in dispute resolution. VAT is a fundamental element of not only Latvian, but also EU's indirect taxation. Latvian VAT legislation is stipulated in the Value Added Tax Law of the Republic of Latvia. A special legislative instrument, a directive, runs in the European Union. With regard to VAT, it is the European Council Directive 2006/112/EC governing the application of VAT in common territory of the EU. This directive is binding on all Member States, however, the Directive allows each Member State to choose their own solutions in some cases.

Given the rapid pace of economic development and economic life, the VAT has become one of the most controversial taxes on several issues in different situations. In order to harmonize EU legislation and ensure protection of legal interests of the taxpayers, the EU Council has made it possible for each Member State to apply to the Court of Justice of the European Union for issue of a preliminary ruling in particularly contentious cases. Interpretation of legislation (preliminary rulings) - the national courts of EU Member States must ensure that EU law is properly applied, but different national courts can interpret them differently. If a national court has doubts about the interpretation or validity of some EU law, it may request an explanation from the Court of Justice of the European Union. The same mechanism can be used to determine whether a national law, its provision or common practice are compatible with the EU law.

Analysis of the decisions made by the tax administration leads to the conclusion that the main increase in tax audit efficiency is often linked to the use of tax administration's prior position in the relation to the taxpayers. This can take the form of imposing additional requirements not provided by law, for example, to assess whether a financial transaction has taken place or not. The Senate of the Supreme Court has granted such powers to the tax administration. 
With regard to the problems with interpretation of legislation concerning the articles of the laws and in the area of application of VAT in particular, there is practice established in Latvia, when the SRS cancels or does not recognize specific past transactions of taxpayers in part based on the tax audits carried out, where VAT pre-tax was previously deducted in accordance with the provisions of the Value Added Tax Law by reducing the VAT payments to the state budget. By questioning the actual process of a transaction, a taxpayer is forced to repay unduly deducted amounts of pre-tax together with a calculated fine back to the state budget regardless the fact whether settlement of accounts in that transaction with its counterparty has taken place or not. This annulment of transactions also constitutes ignoring the provisions of Latvian Law "On Accounting" on the issue of statutory documentary recording of conducted economic transactions. (On Accounting, 1992) Consequences are following: a transaction of a taxpayer is cancelled, additional amounts to be paid to the state budget are calculated, and expenses relating to the amount of corporate income tax are not accepted. There is an approach emerged in the Latvian jurisprudence that is based on the Latvian judicature and is used when assessing and adjudicating compliance with those provisions on their merits. A notion 'judicature' is defined as verity (judgments), which the Supreme Court of the Republic of Latvia has provided a high-quality assessment on interpretation of some provision of the law. Regional and district courts follow those assessments, when assessing similar cases.

Analysing the application of the VAT provisions within the meaning of the Supreme Court of Latvia, the only VAT-referable judicial generalization "Administrative court practice of interpreting and applying the provisions of the Value Added Tax Law" is worth exploring. It clarifies guidance to interpretation and application of the provisions pertaining to pre-tax deduction, mainly on the right to deduct pre-tax and preconditions for emergence of such rights. Having generalized verities provided by the SC, such consistency of actions must be ensured for enforcing the right to deduct pre-tax so that confidence would be gained on setting in of four preconditions, which are explains in interpretation of part one, section 10 of the Latvian Value Added Tax Law by judicature of the SC:

1) An entity is registered in the State Revenue Service as a person taxable with value added tax;

2) It has received goods or services and a value added tax bill is drafted as provided by law;

3) The value added tax bill is received from other person taxable with value added tax, who is registered in the SRS properly;

4) The goods or services received are used for provision of their transactions taxable with value added tax, that is, a new good or service taxable with value added tax is created. (LR AT, 2016)

The Department of Administrative Cases has provided the following adjudgments in addition that the SRS is actively using during tax audits:

1. It shall be established at first, whether a transaction has actually taken place. To qualify for the deduction of pre-tax, the fact that the transactions are processed according to the requirements of the law is not enough, because the transactions must have actually taken place both in their economic and legal nature (on its merits), but a tax bill must comply with the transaction that actually has taken place; (LR AT, 2016)

2. Pre-tax deduction is the right of a taxpayer, that are defined by law, and for an individual to use the statutory subjective right to deduct pre-tax, all of the above mentioned preconditions must be present at the same time. (LR AT, 2016) 
Summarizing the above-mentioned statements, one can conclude that the judicature of the SC of Latvia specifies criteria for evaluating compliance with part one, section 10 of the Latvian Value Added Tax Law and the enforcement of the right to deduct VAT pre-tax:

1) Following execution of a transaction in the form of analysis of VAT documents - its form;

2) Following existence of a transaction by evaluating actual existence of the transaction in reality;

3) Following purpose of a transaction - following features of the good faith or bad faith.

According to the authors, such assessment of a transaction substantiates SRS officials to interpret adjudgments of the SC subjectively. However, for referring to the judicature there must be evidence that clearly enables drawing appropriate conclusions. Consequently, it is important to assess sufficiency, relevance of evidence instead of simply confining oneself to references to the judicature adjudgments. That would not be quite appropriate in any case, because interpretation and application of provisions lie within the competence of courts, whereas objectives of taxpayers and the SRS are to ensure justification of the arguments they put forward.

Having studied the judgements and EU case law in solving the issues under discussion, one concludes that the EU practice differs from the practice applied in Latvia. One of the main problems of proving is obtaining impartial evidence that would be indicative of a taxpayer's malicious intent or the fact that a transaction has not taken place. The authors think that such evidence can be obtained only with the help of operational investigation, which is not included in the mandate of the SRS control service when carrying out tax audits. Consequently, in order to comply with EU practice regarding the matters on application of the rights of VAT pre-tax, it is necessary to review the approach implemented by the SRS and the method of carrying out the tax audit and obtaining required audit evidence as well.

The judicature of Latvia considers many judgments of the tax administration and the administrative court in the area of VAT, which indicate that disputing real existence of an economic transaction is a decisive factor during litigation that is often based only on assumptions or circumstantial evidence in the best case.

Despite the fact that the tax administration has no right to make a decision similar to court judgments, there is a lot of those in practice. A large number of past transactions annulled are not verified by the required evidence, but only assumptions of the tax administration assumptions. The main arguments are focused on the fact that: 1) a counterparty or a taxpayer himself has not had required financial and technical capacities for ensuring the transaction; 2) the taxpayer knew or he had to know that he was involved in schemes of tax fraud; 3) the counterparty has not submitted statutory tax statements. It is very hard for the taxpayer to prove the opposite in retroactively.

As a result, the tax administration carries out collection of necessary evidence incompletely on one hand, because it lacks both financial and intellectual resources, but it is very difficult or even impossible to prove fictitious character of past transactions on the other hand. In such a manner, the tax administration uses the easiest way, as it obliges the taxpayer to look for evidence himself to affirm genuineness of his economic transactions, and these attempts most often fail.

The above-mentioned practice therefore does not respect either the rights of businesses or the principles of audit practice and tax laws, or the general principles of justice. Of course, thus is the way to prevent opportunities for the majority of fraudulent individuals to deduct pre-tax unlawfully by defrauding public money, but it happens at the expense of fair taxpayers. In 
some cases, cancellation of transactions occurs due to absurd reasons such as a transaction is found to be false simply because technical inspection of a vehicle was not carried out during transporting of goods and it had no right to participate in road traffic according to the rules.

The purpose of VAT-related tax auditing is determination of compliance of VAT calculation method with the provisions of tax legislation. So that audit would be legitimate, legally and scientifically sound, the following methods are used during audit (in tax audit as well):

- General scientific (analysis, synthesis, induction method, deductive method, analogy method, modelling, experimental method, functional analysis, etc.);

- Specific (calculation-analytical, documentary, economic-legal);

- Special.

Analysis of court judgments shows that analytical calculations are not used in practice that might justify reality of a transaction or decline it. The results of this study fulfilled by the author of this paperwork approve this practice being used widespread and the lack of sufficient calculations do not interfere with the court procedure from carrying out the final decision. Similarly, it is established that scientific methods are used incompletely, which are known both in auditing and in other disciplines like economic-legal analysis, financial analysis, mathematical modelling, thus violating the general auditing principles such as impartiality and prudence. For this reason, the authors believe that International Standards on Auditing should be used in the practice of tax auditors purposefully. Despite the fact that an independent audit institution is different from an institution of public service, it is not permissible that working standards of tax auditors are not regulated, and methodology of auditing must be clearly applied. From this perspective, the International Standards on Auditing enable producing uniform basic requirements for auditing, when setting regulations of audit quality and reliability, providing a certain level of guarantee for findings of audit inspections, and compliance with the generally accepted practice.

Practice of independent auditors (auditors) is regulated by the International Standards on Auditing (ISAs), which establish the standards for the audit guidelines, for the process of gathering evidence, code of conduct, responsibility of an auditor, contents of a report and other guidelines to be used when conducting an independent audit. ISA 500 "Audit Evidence" governs collection of audit evidence and explains the conditions, under which evidence obtained is sufficient, reliable, and relevant to the audit file. There are methods, approaches, and procedures described that are applied during an independent audit. (IAS 500)

The authors consider that these standards must be also extended to the process of tax audit, taking into account the universally recognized ISAs, by defining a uniform approach, universal and proven methods to restrict provision of low-quality audit service. Criteria of audit quality, compliance of which ISAs require, enable users to rely on the fact that the risk of misleading or incredible information being included in the audited facility is of low probability. Following the principles of ISAs in the area of financial statements allows obtaining reasonable confidence that the information it contains has been verified and is credible. In a similar way, application of appropriate quality criteria in tax audit would make increasing of reliability of the audit findings, raising the prestige of tax administration, and reducing dissatisfaction among taxpayers and a number of initiated court proceedings possible. Given the fact that the findings of tax audit can be called into question not only at a court in Latvia, but also on the international level, the requirements with regard to the evidence obtained during the tax audit must be competitive from the point of view of the international standards as well. 
The analysis carried out during the research points to a number of topical problems of the current period, which should be solved as soon as possible:

1) Non-observance of general judicial principles in the field of respecting the rights of taxpayers;

2) Non-observance of special principles of taxation that contradicts provisions of the tax system;

3) Seriously violations of audit practice, audit principles;

4) In some cases, exaggerated interference of the tax administration in operation of businesses that reduces the efficiency of taxpayers' operation;

5) Increase of administrative costs for entrepreneurs by shifting resources to prove the disputed rights, using services of expensive experts, tax consultants and lawyers;

6) Decreasing number of jobs in bankrupt companies in relation to incapacity to pay additionally surcharged amounts of taxes.

\section{Conclusions and Recommendations}

1. Topicality of the problem is related to increasing proportion of actually uncollectable taxes in the total structure of Latvian state budget, which forms a significant part of the state budget revenue. The State Audit Office of the Republic of Latvia and the European Commission also reflects this problem in their documents and reports.

2. The amounts to be paid as taxes in addition form in the result of tax audits. According to the data of administrative courts in LCP, the SRS of Latvia is the most controversial defendant in disputes with taxpayers, whereas disputable VAT transactions in application of VAT pre-tax are the most controversial subject matter. Due to that, methods and approaches to procedures in the framework of VAT tax audit were studied by summarizing the corresponding criteria determining the quality of audit evidence.

3. The procedures to obtain evidence during an audit are mainly reduced to a formal examination of documents; there was no high-quality application of additional analytical procedures and an assessment system of internal control of business detected.

4. Having exceeded its powers, the SRS allows assessing actual conditions during tax audits, by adopting and interpreting the provisions of tax laws independently, especially those provisions of the laws relating to VAT, even though only the courts have such privilege according to the democratic political system of Latvia. In disputes associated with enforcement of the rights of taxpayers, when applying VAT pre-tax, judicature of the Supreme Court of Latvia is applied, which provides general guidelines for interpreting the provisions of Value Added Tax Law.

5. Individual moments affecting impartiality of the SRS decisions made contradict judgments of the Court of Justice of the European Union. Analysing the judgments of the courts of Latvia, it is concluded that the SRS opinion is often based on the evidence, which cannot be considered impartial, that is, sufficient and referable, from the point of view of the ISAs.

6. In order to address the problems identified during the research, the management of the SRS must train such an expert for tax auditing, who is able to prepare and conduct a professional tax audit in accordance with the practice of the International Standards on Auditing in order to obtain comprehensive and unbiased evidence that would not doubt the quality of evidence at both local and national level. This would ensure protection of the public interest against fraudulent taxpayers, but it would not violate the legal interests of fair businesses at the same time.

7. The Supreme Court of Latvia must reinstate the general conclusion of practice "On Interpretation and Application of the Provisions of the Value Added Tax Law" that has 
not been updated for eight years, thus the latest rulings are missing that can be found in the EU judicature and reflect current practice in the application of the Value Added Tax Law.

8. The duty of a democratic state and the legislator of Latvia is to form such a mechanism of fair public administration that allows protection of the rights of one group without prejudice to the interests of other group. Therefore, it is inadmissible that tax optimization indicating about an open tax evasion is punishable in the framework of administrative cases only. Therefore, if a court judgment states malicious intent of a taxpayer based on verified unbiased evidence, such infringement can no longer be considered in the framework of the VAT Law and cancellation of a transaction cannot be the only punishment, because the information about the stated facts must be notified to law enforcement authorities for initiation of a criminal action for tax evasion in such a case.

\section{References}

Administratīva procesa likuma komentāri. (2013). Autoru kolektīvs. Dr. iur. J. Briedes zinātniskajā redakcijā. Rīga: Tiesu namu aǵentūra, 1058.

Commision Staff working document. Country Report Latvia 2015. Brussels, 26.02.2015. available on-line http://ec.europa.eu/europe2020/pdf/csr2015/cr2015_latvia_en.pdf

Astoņos mēnešos VID administrētie budžeta ieņēmumi par 0,3\% atpaliek no plāna. (2016) available on-line http://financenet.tvnet.lv/zinas/624502astonos_menesos_vid_administretie_budzeta_ienemumi_par_03_atpaliek_no_plana (13.09.2016)

Eiropas Padomes Direktīva 2006/112/EK, available on-line http://eur-lex.europa.eu/legalcontent/LV/TXT/?uri=CELEX\%3A32006L0112 (10.09.2016)

Eiropas Savienības tiesas nolēmumi, available on-line http://at.gov.lv/lv/judikatura/estjudikatura/aktualie-nolemumi/\#3 (31.03.2016)

IAS 500, Audit Evidence, available on-line https://www.ifac.org/publicationsresources/norme-internationale-d-audit-isa-500-1-ments-probants (23.09.2016)

LCP Available on-line https://tis.ta.gov.lv/tisreal?Form=TIS_STAT_O (20.05.2016.)

LR AT tiesu prakses apkopojums administratīvajās lietās. "Par pievienotās vērtības nodokli" normu interpretācijā un piemērošanā", available on-line http://at.gov.lv/lv/judikatura/tiesuprakses-apkopojumi/administrativajas-tiesibas/ ( skatīts 31.03.2016.)

LR VK revīzijas ziņojums Nr.2.4-1-39/2014 par Latvijas Republikas 2014.gada pārskatu ,, Par valsts budžeta izpildi un par pašvaldību budžetiem”. Lpp. 123, 4.att., available on-line http://www.lrvk.gov.lv/uploads//reviziju-zinojumi/2014/2.4-1-

39_2014/sgp_zinojums_01102015.pdf (28.08.2016)

Latvia's Stability Programme for 2015-2018.

Available on-line http://ec.europa.eu/europe2020/pdf/csr2015/sp2015_latvia_en.pdf (30.07.2016)

Nodokḷu kontroles pasākumu rezultāti 2016.gada 1.pusgads (nod.auditi), available on-line https://www.vid.gov.lv/lv/nodok\%C4\%BCu-kontroles-pas\%C4\%81kumu-rezult\%C4\%81ti2016gada-1pusgads-nodauditi (13.09.2016) 
On Accounting. Law of RL (14.10.1992 with amendments to 05.12.2013), available on-line http://www.ttc.lv/advantagecms/LV/tulkojumi/dokumenti.html?folder=\%2fdocs\%2fLRTA\%2 $\underline{\text { fLikumi\%2f\&currentPage }=10}$ (13.05.2016)

On Taxes and Duties. Law of RL ( 02.02.1995. with amendments to 16.12.2015.), available on-line

http://www.ttc.lv/advantagecms/LV/tulkojumi/dokumenti.html?folder=\%2fdocs\%2fLRTA\%2 fLikumi\%2f\&currentPage $=10 \quad(20.06 .2016$.

Par Valsts Ien̦ēmumu Dienestu.(VID LR likums no 28.10.1993.) "Latvijas Vēstnesis", 105, 11.11.1993., "Ziņotājs", 34, 09.12.1993. ( ar grozījumiem 18.06.2015. ieskaitot). available online http://likumi.lv/doc.php?id=59902 (13.09.2016)

Value Added Tax. Law of RL (29.11.2012 with amendments to 17.12.2015.), available online

http://www.ttc.lv/advantagecms/LV/tulkojumi/dokumenti.html?folder=\%2fdocs\%2fLRTA\%2 $\underline{\text { fLikumi\%2f\&currentPage }=10} \quad(13.09 .2016)$ 